Anita Całek

Wydział Polonistyki, Uniwersytet Jagielloński

\title{
Personalistyczny model biografii w świetle zagadnienia podmiotowości
}

Biografia, zwłaszcza ta o charakterze naukowym czy - szerzej faktograficznym wydaje się tekstem niezwykłym $\mathrm{z}$ wielu powodów, o czym świadczy jej nieustająca obecność w literaturze oraz niesłabnąca popularność [Dosse 2011; Kraskowska 2019]. Jako reprezentacja ontologiczna [Markowski 2006] kreuje za pomocą środków literackich bieg życia osoby w kontekście historycznym, społecznym i kulturowym [Całek 2016a], będąc równocześnie tekstem-narracją (naśladującą za pomocą swej fazowej struktury upływający czas i równocześnie uporządkowaną wokół egzystencjalnych tematów typowych dla historii życia) [Całek 2016b, 2017]. Powstaje jako rezultat niezwykłej relacji piszącego z opisywanym [Kendall 1965; Madelénat 1984; Boyer-Weinmann 2005; Dosse 2011; Całek 2013]. Cechuje ją polifoniczność, wielowymiarowość i pograniczność. Źródłem jej wielogłosowości jest mnogość dyskursów, jakie wprowadzone zostają w jej obręb: świadectw, rozmów, opinii, relacji i korespondencji (która będzie stanowić ważny punkt odniesienia dla rozważanych tu kwestii). Przyczyną jej wielowymiarowości jest obecność kolejnych, coraz głębiej zanurzonych w narracji poziomów: od tych najbardziej dostępnych, 
kształtujących samą wypowiedź (określony gatunek biograficzny, figura narratora, model narracji naukowej), poprzez poziom założeń teoretycznych i metodologicznych (porządkujących kwestie związane z trzema najważniejszymi dla biografii obszarami, takimi jak dziedzina aktywności twórcy, kontekst historyczno-społeczny oraz rodzaj i sposób analizy danych biograficznych), aż do leżących u podstaw koncepcji antropologicznych i psychologicznych, które wpływają na sposób rekonstruowania samego biegu życia [Całek 2013].

Ta krótka charakterystyka nie wyczerpuje listy powodów, z racji których biografia na trwałe zakorzeniła się w kulturze, a jej nieustanna żywotność oraz popularność, zarówno wśród badaczy, jak i odbiorców ich prac, wskazuje na to, jak ważne miejsce zajmuje ona w świadomości czytelniczej, będąc często wybieraną spośród wielu innych gatunków (literackich i naukowych). Szczególny charakter narracji biograficznej wynika z jeszcze jednego zaskakującego połączenia, które dotąd rzadko stawało się tematem osobnych analiz. Otóż biograf czyni przedmiotem swych badań historię życia określonej jednostki, której nie da się oderwać od niej samej. Z tego też powodu nieustannie balansuje na granicy przedmiotowego traktowania bohatera biografii (jako obiektu swych badań) i równoczesnego etycznego obowiązku uwzględniania jego podmiotowości. To właśnie pogranicze stanowi równocześnie zagrożenie i szansę. Zagrożenie, gdyż odnosi się do wartości i godności osoby ludzkiej postawionej w roli obiektu badań, co musi rodzić dylematy i prowadzić do napięć. Jednak sytuację tę można i warto postrzegać również jako szansę na uwypuklenie problematyki samej podmiotowości oraz problematyki osoby w biografii: kwestie te staną się centralnym zagadnieniem dla niniejszych rozważań. cony w całości problematyce biograficznej, jednakże zaproponowane ujęcia teoretyczne również nie dotykały tej kwestii, być może nazbyt skupione na przeszłych, a nie aktualnych nurtach badań biograficznych [Legeżyńska 2019; Nasiłowska 2019]. 


\section{Biografia jako narracja, relacja i reprezentacja}

W refleksji nad biografią jako gatunkiem wypowiedzi długo przyjmowano implicite, iż naukowy charakter opracowania lub nawet charakter faktograficzny wymazują problematykę podmiotu biografii. Narratora tekstu biograficznego kreowano na przezroczyste medium, a jego nieobecność, chociaż miała wyłącznie charakter językowy (wyrażający się w neutralności zwrotów lub też ukrywaniu metanarracji za formami trzecioosobowymi), była traktowana jako pewnik, o czym najlepiej świadczy definicja biografii zamieszczona w Słowniku terminów literackich [Sławiński 200o]. Narrację opisywano w nim jako rodzaj spoiwa łączącego wydarzenia i dokumenty biograficzne w sensowną całość. Pod tym względem biografia „czysto dokumentalna” miała być wyłącznie „montażem wyciągów ze źródeł dotyczących życia bohatera” o „zredukowanych do minimum” elementach narracyjnych. Ujęcie to, ze współczesnej perspektywy o znaczeniu wyłącznie historycznym, pozostaje świadectwem nieaktualnego już podejścia metodologicznego do biografii [por. Madejski 2006; Całek 2013, 2016ab; Legeżyńska 2019].

Dziś już wiadomo, że jest zupełnie inaczej3: narrator, będący dysponentem reguł re-konstruowania biografii (a zatem ponow-

2 Nieco inaczej była widziana biografia literacka (zbeletryzowana, dopuszczająca fikcję), w której można było stosować wszystkie techniki powieściowe, zatem i narracja podlegała innym zasadom [Sławiński 200o]; w dzisiejszym piśmiennictwie naukowym kategorie faktyczności i fikcjonalności ulegają redefinicjom - np. $\mathrm{w}$ postaci wprowadzenia pojęcia faction [Tabaszewska 2019] czy biofikcji [Kraskowska 2019]. Warto jednak przypomnieć, że osobny artykuł na temat fikcjonalizacji biografii i pojęcia biomitografii zaproponowała już Aleksandra Chomiuk [2016]. Niezależnie od tego zagadnienia nie można pominąć problematyki „mocnego podmiotu” biografii, ujawniającego się w takich figurach narratora, jak detektyw, reporter, demaskator czy turysta [Całek 2013]. Refleksje na temat współobecności biografa-narratora (czasem utożsamianego, czasem nie z autorem) pojawiały się w przypadku analiz konkretnych przykładów nietypowych opowieści biograficznych (np. Jarosława Marka Rymkiewicza), jednak nie prowadziło to do przeformułowania wyjściowego założenia o neutralności narracji i było traktowane jako przejaw literackości nawet w tekście charakteryzującym się wysokim stopniem faktograficzności - jak w przypadku Rymkiewicza.

3 Poniższe rozważania są rekapitulacją kwestii analizowanych w monografii Biografia naukowa: od koncepcji do narracji [Całek 2013] oraz w artykułach Biografia 
nego jej konstytuowania na zasadzie reprezentacji o charakterze ontologicznym [por. Markowski 2006]), to tekstowy „gospodarz biografii" niezależnie od stopnia ujawniania się w narracji. Jego „neutralność” jest nieuchronnie pozorna, gdyż nadal (jako tekstowe odzwierciedlenie przekonań i postaw autora) przyjmuje określoną perspektywę badawczą, selekcjonuje fakty i świadectwa, omawia szerzej lub krócej dane wydarzenia. Obecność ta ujawnia się we wszystkich głębszych wymiarach biografii [Całek 2013: 173-183]; z tego powodu jego podmiotowość przyjmuje postać syllepsis. Ryszard Nycz [2002: 109] definiuje podmiotowość sylleptyczną następująco:

"Ja” sylleptyczne - mówiąc najprościej - to „ja”, które musi być rozumiane na dwa odmienne sposoby równocześnie: a mianowicie jako prawdziwe i jako zmyślone, jako empiryczne i jako tekstowe, jako autentyczne i jako fikcyjno-powieściowe ${ }^{5}$.

Narrator biografii ma charakter sylleptyczny, gdyż jednocześnie ujawnia autora i ukrywa go pod postacią wykreowanej figury narracyjnej [Całek 2013], co zarazem przybliża ten gatunek do literatury i wskazuje na element kreacyjny oraz autoprezentacyjny reprezentacji biograficznej, nieuchronnie obecny we wszystkich gestach autorskich ujawniających władzę badacza nad tekstem biografii (nawet tej faktograficznej). Elementy autoprezentacyjne biografa i kreacyjne działania w jego relacji do twórcy nie dają się oddzielić, gdyż nie ma takiego „punktu narracyjnego”, który gwarantowałby badaczowi obiektywny, chłodny ogląd. Jest on zawsze zaangażowany w tekst, wchodzi weń całą swoją osobą, wnosząc to, kim jest, co wie, co reprezentuje, co myśli o bohaterze biografii

jako reprezentacja [Całek 2016a] i Narrator biografii naukowej: między referencyjnością a fikcja [Całek 2016b]. Tezy tam uzasadnione traktuję jako założenia wyjściowe w analizie problematyki podmiotowości w biografii, a dla jasności wywodu krótko je przedstawiam.

4 Terminem tym nawiązuję do zaproponowanej przez Kazimierza Wykę [1963] kategorii "gospodarza poematu” w analizie Pana Tadeusza.

Jest to - posługując się stwierdzeniem, które pada w dalszej części tekstu - „pisanie sobą”. Temat „sobąpisania” w ostatnim czasie obszernie omówiła Roma Sendyka [2015]. 
i jego epoce [Całek 2016b]. Pisanie biografii jest bowiem relacją, jak to przedstawia Martine Boyer-Weinmann [2005], relacją między piszącym a opisywanym, która ma swój aspekt etyczny, estetyczny i epistemologiczny. Biografia rodzi się „pomiędzy”, stając się lustrem, które odbija równocześnie i historię życia bohatera biografii, i oblicze autora tekstu ${ }^{6}$. Po części jest więc także jego własną autobiografią.

O tej specyficznej relacji pisał już zresztą Paul Murray Kendall [1965]. Zaproponował nawet osobną kategorię - biografii podwójnie zaangażowanej. Biografia ta ma charakter symbiotycznej relacji między piszącym a opisywanym; biograf musi zatem mieć świadomość autobiograficznego charakteru tak tworzonego portretu Innego, gdyż świadomie wchodzi w empatyczną, emocjonalną relację ze swoim bohaterem, by móc lepiej oddać jego przeżycia i doświadczenia, „dać im życie”, posługując się określeniem samego Kendalla [1965: 149].

Myśl tę rozwijał we Francji Daniel Madelénat [1984], który ową relację postrzega w bardziej radykalny sposób. Według niego biograf musi pozwolić „przyjść umarłym do siebie”, a relacja biograficzna przypomina związek, w którym na przemian następuje panowanie i podległość, sympatia i zazdrość, fascynacja i niechęć. Biograf staje się rezonatorem, towarzyszem swego bohatera, a doświadczenie to przełamuje granice między piszącym a opisywanym, każe przyjąć mu w siebie „ciało obce” [Madelénat 1984: 92-94]. François Dosse [2011] pisze z kolei o „kontrakcie lekturowym" zawartym między nadawcą i odbiorcą biografii, przywołując pojęcie "paktu biograficznego" w formule zaproponowanej przez Philippe’a Lejeune’a [2001]. Ujęcie to, doprecyzowane w innym miejscu [Całek 2013], pozwala opisać istotne strony tego paktu (biografa, bohatera biografii, rodzinę i bliskich oraz czytelników), między którymi tworzą się trzy możliwe relacje działające na zasadzie paktu biograficznego: między biografem a bohaterem

6 Potwierdzeniem tego jest autokomentarz Andrzeja Franaszka [2019] na temat przygotowywania biografii Zbigniewa Herberta, w którym badacz zwracał uwagę nie tylko na egzystencjalny walor procesu pisania biografii, ale i relację, a nawet więź, jaka powstaje podczas odczytywania archiwów czy tropienia śladów i świadków biegu życia tego, którego się opisuje. 
biografii (relacja biograficzna podlega zatem regułom tego paktu), między biografem a rodziną i bliskimi opisywanej postaci (pełnią oni funkcję dysponentów źródeł biograficznych) oraz między biografem a czytelnikiem (który, biorąc do ręki tekst nazwany biografią, traktuje to określenie jako rodzaj zobowiązania do mówienia prawdy i tylko prawdy na temat historii życia danej postaci).

Biografia, będąc reprezentacją, która wytwarza za pomocą środków literackich (na zasadzie rzeczywistości wykreowanej kulturowo [Zagórska 2004]) symboliczne miejsce przecięcia się linii czasu czytelnika i bohatera biografii, przenosi go w czasie i przestrzeni, pozwalając odbiorcy na doświadczenie „tekstowego ekwiwalentu" relacji interpersonalnej. Aby było to możliwe, reprezentacja ta musi być zakorzeniona w faktach (historycznych, biograficznych) oraz świadectwach (wypowiedziach samego bohatera biografii). Wrażenie przeniesienia się w przeszłość i spotkania bohatera biografii to efekt oddziaływania tekstowej specyfiki samej reprezentacji, która korzysta z chwytów literackich umożliwiających naśladowanie rzeczywistości, zwłaszcza sekwencyjnego porządku i następstwa faz życia opisywanego w kontekście historyczno-kulturowo-społecznym. W tym sensie biografia kreuje świat miniony (zakorzeniony w wiedzy historycznej biografa i w jego wyobraźni), oddając główne miejsce w tak przygotowanej „scenerii” bohaterowi biografii. Za pomocą środków fabularnych, na podstawie chronologii wydarzeń, naśladuje upływ czasu potrzebny do uzyskania „efektu” biegu życia. Pisarz w biografii tworzy przestrzeń spotkania z osobą (konstruując syl-

O tym, że tak się właśnie dzieje, następująco pisze Franaszek [2019: 255], odwołując się do własnych doświadczeń: „Pisząc biografię, na swój sposób, oczywiście bardzo ułomny, znajdujemy się w podobnym punkcie. Na tyle, na ile potrafimy wsłuchujemy się w głosy zmarlych. [...] Teraz jednak czytamy ich listy, zaczynamy darzyć sympatią, przebywamy wraz z nimi w dziwnej przestrzeni, zawieszonej między dwoma światami. Bo z jednej strony siedzimy samotnie w czytelni, powiedzmy londyńskiego Posk-u, [...] ale z drugiej, otwierając kolejną teczkę, otrzymujemy ekstrakt cudzego życia, tak odległego od naszego czasu”. Jesteśmy «tu», ale również «tam» - we Lwowie lat 40. albo w Krakowie dwie dekady później [...]. Jakkolwiek zabrzmi to patetycznie, płacąc cenę smutku, odwiedzamy krainę śmierci - i z podróży tej wracamy odmienieni. Może nawet nieco mądrzejsi i bardziej wyrozumiali wobec żywych”. 
wetkę głównego bohatera w rozwoju) oraz osadza ją w świecie odzwierciedlającym jego wyobrażenie przeszłości [Całek 2016b].

Biografia jest zatem reprezentacją, która uobecnia nieobecnego twórcę, a po jego śmierci symbolicznie go zastępuje, czyli re-prezentuje [Całek 2016b]. Z tego względu powinna być z jednej strony naukowo rzetelna i sprawiedliwie oddająca przeszłość, zgodnie z rozumieniem, jakie temu ujęciu nadał Frank Ankersmit [2004], a z drugiej - dążąca do prawdy i jej jako wartości nieustannie poszukująca: prawdy o życiu opisywanej postaci nie tylko w całym bogactwie jego zewnętrznych przejawów, ale i w dociekaniu prawdy wewnętrznej, subiektywnej, której dysponentem pozostaje wylącznie bohater biografii.

$\mathrm{O}$ ile pierwsze z tych założeń jest dziś powszechnie popierane we współczesnej refleksji nad biografią i jej tekstową specyfiką, o tyle drugie dzieli badaczy. Można wyróżnić wśród nich dwie znaczące grupy: zwolenników koncepcji ponowoczesnych (reprezentujących podejście socjologiczne, psychoanalityczne czy feministyczne [por. Elliott 2007]), którzy rezygnują z koncepcji prawdy (a w skrajnych postaciach kwestionują w ogóle jej sensowność), oraz badaczy, którzy - przeszedłszy fazę dekonstrukcjonizmu i doceniwszy jej krytyczny potencjał - nie zatrzymali się na tym, lecz nadal poszukują prawdy w prowadzonych przez siebie badaniach naukowych. Prawdę tę formułują już na nowych zasadach: nie w odniesieniu do strukturalistycznego mitu „obiektywizmu badań naukowych” oraz „niezależności badacza”, lecz ze świadomością ograniczonego charakteru i zakresu swoich hipotez, a także ich kulturowego, kontekstowego zakorzenienia.

\section{Antropologie redukcjonistyczne a personalizm w biografii}

Jakościowa odmienność tekstu biograficznego, którego bohaterem jest osoba faktycznie istniejąca (jej życie w świecie empirycznym potwierdzają daty graniczne narodzin i śmierci), w przeciwieństwie do tekstowej egzystencji bohatera literackiego w fikcji, jest przedmiotem sporów pomiędzy reprezentantami rozmaitych podejść ponowoczesnych a personalistami. Rysujące się na tym tle napięcie pomiędzy prawdą a fikcją może uzyskać - w kontek- 
ście wyboru orientacji teoretycznej i metodologicznej - dwie zasadniczo różne realizacje, wynikające z podstawowych założeń epistemologicznych i antropologicznych ${ }^{8}$.

Ponowoczesna koncepcja biografii, w świetle której postrzega się narrację biograficzną jako nieuchronnie literaturyzowaną, a nie faktograficzną rekonstrukcję życia, zaciera granicę między prawdą a fikcją. W jej ramach osoba historyczna i postać fikcyjna uzyskują analogiczny status, a biograf nie ma wobec bohatera biografii żadnych zobowiązań etycznych ani epistemologicznych, gdyż tworzy tekst z zamierzenia literacki, a zatem fikcyjny. Istotą tej koncepcji jest często dekonstrukcyjne, obnażające sposoby budowania narracji, samozwrotne spojrzenie, a dociekanie prawdy zostaje zastąpione analizą procedur jej wytwarzania. W ten sposób narracja biograficzna traci swą wyłączną „orientację na podmiot”; służy po części weryfikacji własnych założeń i procedur lub też świadomie rezygnuje z nieosiągalnego obiektywizmu na rzecz subiektywnej, autorskiej reprezentacji, niezobowiązanej do wiernego (wiarygodnego) reprezentowania przeszłości.

Biografia odwołująca się do modelu poststrukturalistycznego ufundowana jest na antropologiach redukcjonistycznych, ujmujących człowieka jako byt wyłącznie biologiczny, historyczny, psychiczny czy socjologiczny; do najpopularniejszych ujęć antropologicznych należą koncepcja biologiczno-ewolucyjna (w dwóch odmianach: marksistowskiej koncepcji człowieka oraz psychoana-

8 Co ciekawe, zwolennicy koncepcji ponowoczesnych - co doskonale uświadamia praca Anthony'ego Elliotta Koncepcje ,ja”, traktowana chociażby przez Zygmunta Baumana jako wyraz przekonań szerokiego, zróżnicowanego środowiska myślicieli współczesnych - pomijają milczeniem odmienne podejścia, sytuując się na pozycji dominującej i w zasadzie traktowanej jako bezkonkurencyjna. Gdy Elliott [2007: 19] pisze przykładowo o problematyce jaźni, wskazuje wyłącznie te nurty myślenia, które reprezentują jedną, redukcjonistyczną i materialistyczną antropologię: „Zarówno w obrębie freudyzmu, jak też feminizmu, poststrukturalizmu i myśli ponowoczesnej, jaźń jest zawczasu zdeterminowana przez rozmaite siły polityczne i historyczne, włączając w nie system stosunków społecznych, pragnienia i języka”. Dla zrównoważenia tego obrazu, który nie uwzględnia dynamicznie rozwijających się koncepcji personalistycznych, warto przeznaczyć więcej miejsca na prezentację właśnie tego kierunku, aktywnie ignorowanego przez przedstawicieli dominującego nurtu refleksji nad podmiotowością w filozofii i naukach społecznych. 
lizy), a także strukturalizm [Szymonik 2015]. Ten ostatni nazywa Szymonik [2015] „najbardziej krańcowo redukcjonistyczną interpretacją człowieka”, gdyż ogranicza osobę do „bytu mówiącego”, o czym pisze również szeroko i równie krytycznie Mieczysław A. Krąpiec [2003]. Odrzuca zresztą także psychoanalizę jako mylną ze względu na to, że traktuje świadomość człowieka jako fenomen wtórny w stosunku do nieświadomości.

Marian Szymonik [2015: 49-50], prezentując redukcjonizm współczesnych koncepcji antropologicznych, pisze tak:

Można powiedzieć, że redukcjonistyczne antropologie są najpierw zapowiedzią, a potem wykonawcą dramatu „śmierci człowieka”. Szczególna rola przypada w tym względzie strukturalizmowi, który stanowi ostatnią fazę ,uśmiercania człowieka”. Redukcjonistyczne antropologie przygotowują także grunt pod postmodernistyczne uśmiercenie ludzkiego podmiotu.

Badacz zwraca również uwagę na materialistyczność ponowoczesności, której konsekwencją jest antypersonalizm, prezentowany w myśli Jacques’a Derridy, Michela Foucaulta czy Richarda Rorty'ego [Szymonik 2015]. „Decentrowanie podmiotu” jako wytworu systemów językowych bądź symbolicznych, o którym pisze Anthony Elliott [2007: 21], zostało dokonane „w oparciu o założenia wywodzące się z poststrukturalizmu, teorii dyskursu i psychoanalizy" i doprowadziło do redefinicji pojęcia tożsamości jako rozproszonej, fragmentarycznej, elastycznej, niestabilnej i podlegającej ciągłej rekonstrukcji; postrzeganej odtąd głównie w ramach takich kategorii, jak płeć kulturowa, seksualność, rasa, etniczność, wielokulturowość, władza czy przynależność klasowa [Elliott 2007: 21-23, 26]. Odrzucenie podmiotowości doprowadziło $w$ konsekwencji do rezygnacji z poszukiwania prawdy z racji jej uwikłania w uwarunkowania ludzkiego poznania, a zatem do odrzucenia pojęcia „badania rzeczywistości” na rzecz arbitralnego „wytwarzania jej obrazu” przez „słaby podmiot” o płynnej, nieustalonej tożsamości.

Alternatywę dla tej dotąd dominującej orientacji teoretycznej stanowi właśnie współczesny personalizm ze względu na orien- 
tację antropocentryczną oraz stawianie w centrum zagadnienia osoby i jej „mocnej podmiotowości”. Antropologia personalistyczna dobrze wpisuje się w zagadnienia rozstrzygane przez badaczy biografii, pozwalając na pogłębienie wątków związanych ze specyfiką istnienia człowieka jako osoby - nawet jeśli ujmować go w nurcie czasu i jednostkowo (jako głównego bohatera własnej historii życia). Praca nad biografią określana jest wówczas jako akt odmienny od pisania każdego innego tekstu: w jej centrum stoi bowiem osoba, którą nie można się posłużyć (choćby dla udowodnienia najbardziej słusznych naukowych hipotez) i której życia się nie posiada ani też praw do jego przepisywania czy przeformułowywania. Dlatego też życie bohatera biografii postrzeganej w kategoriach personalistycznych nie podlega prawu literaturyzacji, nie jest też tekstem, który można dowolnie interpretować. Postępowanie badacza powinna zatem cechować odpowiedzialność za wizerunek wytwarzany w postaci narracji biograficznej. Jest to istotne ze względu na performatywny charakter biografii, która formuje w kulturze wyobrażenia danej osoby i ma wpływ na ukształtowanie w społeczeństwie trwałych postaw oraz ocen konkretnych postaci historycznych. $\mathrm{Z}$ tego względu zagadnienia etyczne związane $z$ aktem pisania tak ujmowanej, personalistycznej biografii stają się równie ważne jak kwestie epistemologiczne (pisze o tym - z perspektywy praktyka i w odniesieniu do biografii Zbigniewa Herberta - również Andrzej Franaszek [2019]).

Różnica wynikająca ze szczególnego statusu osoby w biografii tworzonej zgodnie z normami personalizmu staje się istotna i wyraźna, gdy problem ten zostanie postawiony wobec refleksji na temat osoby oraz podmiotowości, która

pokazuje, iż człowiek jest fundamentalnie kimś innym wobec świata przedmiotowego, że bycie racjonalną osobą wyróżnia go spośród świata rzeczy, które są przedmiotowo zawsze tylko czymś. To proste, elementarne rozróżnienie ujawnia głęboką przepaść, jaka dzieli świat osób od świata rzeczy. [Drożdż 2016: 23 ] 
Wobec tak widocznych zbieżności w badaniach nad problematyką osoby i specyfiką jej istnienia w świecie między antropologią personalistyczną a biografiką wydaje się zaskakujące, że sama filozofia personalizmu - mimo jej niezwykle bujnego rozwoju w Xx i XxI wieku - nie stała się dotąd istotnym źródłem inspiracji dla badań literackich. Podstawy ku temu dawały w przeszłości prace dwóch autorów: Tymona Terleckiego [1987], który swoje dwie rozprawy Krytykę personalistyczną oraz Egzystencjalizm chrześcijański - opublikował już w latach 1957-1958, a także Krzysztofa Dybciaka [1981], autora jedynej literaturoznawczej monografii poświęconej personalizmowi z lat 30. Względy historyczne i ideologiczne ograniczyły jednak wpływ nurtu personalistycznego na literaturoznawstwo ze szkodą dla badań biograficznych. Z tego względu warto dziś powrócić do tego nurtu filozofii, czyniąc z antropologii personalistycznej w jej współczesnym kształcie podstawę biograficznej koncepcji osoby konkurencyjną do modelu ponowoczesnego. Aby tak się stało, należy jednak sięgnąć po dynamicznie rozwijające się koncepcje nadal aktualne i dyskutowane (Dybciak pisał o okresie międzywojennym, traktując personalizm jako zjawisko historyczne, podczas gdy jest on obecnie nadal szeroko reprezentowanym w filozofii nurtem, zwłaszcza jeśli chodzi o kontekst polski).

$\mathrm{Z}$ tego też względu prezentując nowy, personalistyczny model biografii współczesnej, będę sięgać po takie koncepcje, które mogą stanowić dla niego podstawę filozoficzną i antropologiczną. Wykorzystam zatem Dziesięć tez na temat osoby Viktora E. Frankla [2017], odwołam się również do najwybitniejszych przedstawicieli personalistycznej szkoły lubelskiej', takich jak Karol Wojtyła [1969, 1986, 1999], Krąpiec [2003], Czesław Stanisław Bartnik [2006, 2012] czy Tadeusz Styczeń [2001]. Sięgnę jednak również po prace wyrastające z myśli Wojtyły, ale formułowane w odniesieniu do

Z oczywistych względów dokonany na potrzeby biografistyki przegląd koncepcji personalistycznych ma ograniczony i wybiórczy charakter, nie jest też w żadnej mierze reprezentatywnym ani historycznym przeglądem poszczególnych nurtów personalizmu; jeden i drugi można znaleźć $w$ wielu pracach poświęconych temu nurtowi [por. Czarkowski 1994; Bartnik 2006; Kowalczyk 2014; Szymonik 2015; Granat 2018]. 
współczesności [Galarowicz 2009], oraz po obecne rozumienie normy personalistycznej, również po raz pierwszy sformułowanej przez Wojtyłę [1986].

\section{Frankl i jego Dziesięć tez na temat osoby}

W roku 1950 swoje credo filozoficzne i antropologiczne w postaci Dziesięciu tez na temat osoby przedstawił Frankl [2017], twórca logoterapii - tzw. trzeciej szkoły wiedeńskiej, czyli psychologii egzystencjalnej. Ten w Polsce wciąż zbyt mało znany myśliciel, uczeń Zygmunta Freuda i Alfreda Adlera, który - odrzuciwszy psychoanalizę - samodzielnie sformułował koncepcję poszukiwania sensu oraz gotowości życia i umierania dla wartości, oparł swą filozofię człowieka na własnym doświadczeniu Zagłady. Jego tezy okazują się zbieżne z założeniami współczesnego personalizmu, chociaż sam psycholog nawiązywał przede wszystkim do teorii psychologicznych, nie uciekając jednak przed rozważaniami o naturze człowieka.

Dziesięć tez na temat osoby [Frankl 2017; Całek 2019b] to tekst $\mathrm{z}$ jeszcze jednego powodu istotny w kontekście niniejszych rozważań. Mógłby bowiem w całości stać się manifestem personalistycznego podejścia do biografii, oczywiście po zaadaptowaniu do tego rodzaju badań. Wskazując na zaistniałe ważne zbieżności, wyznaczające kierunek badań nad osobą zarówno w psychologii egzystencjalnej, jak i w biografii pisanej w duchu antropologii personalistycznej, będę zatem starała się również wskazać narzędzia i sposoby, za pomocą których biograf może przełożyć każdą z tez na wytyczne o charakterze teoretycznym bądź metodologicznym.

Pierwsza teza Frankla [2017] głosi, iż osoba jest jednostką, czyli niepodzielną jednością. Jest też całością (druga teza), co oznacza, że nie może zostać scalona z czymkolwiek (ani przyporządkowana do pojęć wyższego rzędu, takich jak zbiorowość ludzka, klasa, rasa). Istnieje jako absolutne novum, gdyż duchowa egzystencja nie podlega dziedziczeniu, kształtowana jest indywidualnie w biegu życia każdego człowieka (teza trzecia). Respektując te trzy założenia, badacz biografii pisanej w ujęciu personalistycznym powinien zatem postrzegać bohatera zawsze jednostkowo, nie 
czyniąc z jego życia ani „reprezentatywnej biografii pokoleniowej” (gdyż to automatycznie prowadzi do uprzedmiotowienia osoby opisywanej), ani też odwrotnie - nie traktować kontekstu (tła historycznego, socjologicznego czy ekonomicznego) jako podstawowego źródła wyjaśnień biograficznych; nie powinien również ograniczać ich do tegoż. Jest też zobowiązany do nieustannej wrażliwości na podmiotowy charakter tworzonej biografii, gdyż opisuje unikatowe, absolutnie jednostkowe istnienie, a nie „typ” czy „przedstawiciela epoki”, niezależnie od stopnia faktycznego podobieństwa indywidualnej biografii do modelu obowiązującego w danej rzeczywistości społeczno-historycznej.

Według czwartej tezy Frankla osoba ma naturę duchową, ale potrzebuje organizmu, by działać i mieć możliwość ekspresji. Ze względu na bycie osobą jednostce przysługuje godność niezależnie od jej użyteczności. W punkcie tym psycholog zwraca uwagę na rolę szacunku wobec osoby chorej nieuleczalnie albo zmagającej się z zaburzeniami psychicznymi. Wskazuje, że nawet w psychozie pod powierzchnią objawów psychotycznych wciąż istnieje osoba duchowa - w innym przypadku żadna terapia nie miałaby sensu. Zdanie to nazywa Frankl swym psychiatrycznym credo. Omawia również „psychologię bez ducha”, która nie uwzględnia ani godności osoby, ani świata wartości, wyraźnie krytykując podejście psychoanalityczne:

W projekcji psychologicznej sumienie staje się superego, względnie „introjekcją” imago ojca, a bóg „projekcją” tego imago - podczas gdy w gruncie rzeczy ta interpretacja psychoanalityczna sama jest projekcją, a mianowicie projekcją psychologistyczną. [Frankl 2017: 261-262]

Z perspektywy biografii personalistycznej deklaracja ta jest podwójnie ważna: po pierwsze, wyjaśnia zdystansowanie się od psychoanalizy (w każdym jej ujęciu, dziś zwłaszcza lacanowskim); po drugie, zwraca uwagę na problematykę cielesności i uobecnienia osoby w tekście, równie ważną co zagadnienie jej duchowości.

Zgodnie z tezą piątą natura osoby jest egzystencjalna, przez co Frankl [2017: 263] rozumie to, że 
osoba nie jest bytem faktycznym, nie przynależy do sfery faktualnej. Człowiek jako osoba nie jest istotą faktualną, lecz fakultatywną. Egzystuje jako swój własny potencjał, jako możliwość, za którą albo przeciwko której można się opowiedzieć.

Definiując ten aspekt, Frankl przywołuje Karla Jaspersa i jego bycie egzystencją „decydującą”, ciągle otwartą na możliwości (a nie miotaną popędowością jak w psychoanalizie). Przypomina też pojęcie odpowiedzialności za siebie, które oznacza dla jednostki więcej niż samą wolność: osoba jest bowiem zorientowana na sens i nie dąży ani do przyjemności (Freud), ani do mocy (Adler), ale do wartości ${ }^{10}$. $\mathrm{Z}$ tego względu biografia personalistyczna powinna tak kształtować reprezentację biograficzną, by wydobyć ów rozwojowy charakter oraz podmiotowy wymiar dokonywanych przez jednostkę wyborów. Nie są one motywowane popędowo (jak w psychoanalizie), lecz nakierowane na wartości. Mówi o tym również szósta teza Frankla, który podkreśla, że „Osoba ma naturę Ja, a nie to czy Id” i nie jest od dyktatu Id zależna; nie można jej też wywieść $\mathrm{z}$ warstwy popędowej [Frankl 2017: 264]. Dysponuje jednak nieświadomością, która ma naturę duchową:

U źródła, u podstaw duch jest nierefleksyjnym i w tej mierze nieświadomym czystym dokonaniem. Musimy więc bardzo dokładnie odróżniać ową popędliwą nieświadomość, z którą wyłącznie miała do czynienia psychoanaliza, od nieświadomości duchowej. Do nieświadomości duchowej przynależy również nieświadoma pobożność, nieświadoma religijność - jako nieświadoma, nierzadko wyparta, wrodzona więź człowieka $\mathrm{z}$ transcendencją. [...] ku wierze w boga i ku zawierzeniu bogu nigdy nie popycha mnie popęd, lecz ja sam muszę się za nim lub przeciwko niemu opowiedzieć. Religijność jest domeną „ja”, inaczej w ogóle jej nie ma. [Frankl 2017: 264] niej). 
Także w tezie siódmej Frankl podkreśla, iż osoba jest nie tylko całością i jednością, ale również ustanawia jedność i całość (tworząc fizyczno-psychiczno-duchowy byt zwany człowiekiem). Z tego względu osoba stanowi „punkt przecięcia, krzyżowania się trzech warstw istnienia: cielesnej, psychicznej i duchowej. Owych warstw nie da się od siebie zupełnie oddzielić” [Frankl 2017: 264]. Biograf, chcąc wytworzyć reprezentację życia jak najbardziej wiarygodną i zbliżoną do prawdy, powinien zatem respektować obecność wszystkich trzech wymiarów, opisując egzystencję danego twórcy. Pominięcie którejkolwiek sfery: cielesnej, psychicznej lub duchowej - w sposób istotny i nieodwracalny zniekształci obraz biografii, gdyż nie odzwierciedla natury opisywanego człowieka jako osoby.

Dopełnieniem tej zasady jest teza ósma, mówiąca o tym, że osoba jest dynamiczna i może się zdystansować od swojej warstwy psychofizycznej:

Egzy-stencja oznacza zdolność do wyjścia z siebie i stawienia sobie samemu czoła. Człowiek stawia czoła sam sobie w tym zakresie, w jakim jako osoba duchowa stawia czoła swojej psychofizyczności. Właśnie owo dystansowanie się od siebie samego jako organizmu psychofizycznego konstytuuje osobę duchową jako taką. Dopiero gdy człowiek targuje się sam ze sobą, wyodrębnia się jego duchowość i psychofizyczność. [Frankl 2017: 265]

Wymiar ten stanowi jedną z najgłębszych cech człowieczeństwa ${ }^{11}$, dlatego też powinien być obecny w każdej biografii jako jej istotny element. Współgra z nim teza dziesiąta, w której Frankl podkreśla, iż „Osoba rozumie samą siebie tylko z poziomu transcendencji”, a jej wezwanie słyszy w swoim sumieniu. Logoterapia dostosowuje się i do światopoglądu teistycznego (wówczas zakłada wiarę w Boga), i do ateistycznego ( $w$ takiej sytuacji odwołuje się do wiary w sens). Frankl [2017: 266] przywołuje tu zdanie Alberta Einsteina, iż bycie osobą religijną jest równoznaczne ze stawia- 
niem pytań o sens życia. Wydaje się że te właśnie pytania są równie ważne dla samej biografii, która w całości stara się odpowiedzieć na nie, wskazując celowość danej jednostkowej egzystencji, jej wielowymiarowość, kontekst, wielorakie uwikłania oraz złożoność tego opisywanego istnienia w jego wymiarze osobowym - konkretnego bohatera biografii.

Przestawione powyżej Dziesięć tez na temat osoby stanowi najpełniejszy wyraz przekonań Frankla. Dla biografii personalistycznej może jednak tworzyć fundamenty antropologiczne: w ich centrum stoi mocny podmiot (podlegający dynamicznym zmianom i nieustannie redefiniujący Siebie), a prawda o nim - zanurzona w subiektywności epistolograficznej ekspresji, poddana konfrontacji z Innymi i wreszcie wystawiona na intersubiektywną analizę badacza, który dąży do jej pełnego zrozumienia i opisania, a następnie uogólnienia - jest głównym powodem zainteresowania danym biegiem życia. W formie narracji biograficznej uzyskuje on konkretny kształt, stając się kulturową reprezentacją egzystencji jednostki, jej symbolicznym obrazem, kształtującym powszechny odbiór i formującym określony obraz danej osoby.

Co warte zauważenia, tezy Frankla zostały sformułowane niezależnie od dynamicznie rozwijającego się personalizmu filozoficznego, mimo wyraźnej zbieżności - być może ze względu na to, że badacz świadomie odnosił się przede wszystkim do dominujących wówczas w psychologii nurtów (psychoanalizy i behawioryzmu) i aby wejść z nimi w spór, wolał pozostać na gruncie psychologii, zwłaszcza iż wiązał swoją koncepcję z terapią (jako autor logoterapii nakierowanej na poszukiwanie sensu i wartości przez człowieka). Trudniej natomiast wyjaśnić, dlaczego tezy te zostały zignorowane przez samych personalistów; jeśli chodzi o kontekst polski, być może wynikało to z małej dostępności prac Frankla, które dopiero w ostatnim czasie zostały przełożone na język polski. Niezależnie od tego, iż trudno wobec zaistniałych faktów wskazać czynione wprost nawiązania pomiędzy Franklem a omawianymi poniżej przedstawicielami filozofii personalistycznej, należy zauważyć związki na poziomie idei oraz niezależnie uobecniające się zbieżności w podejściu do fenomenu człowieka jako osoby. 


\section{Personalistyczna koncepcja osoby jako antropologiczna podstawa biografii}

Wojtyła w roku 1949 (a zatem niemal równolegle z tezami Frankla) wygłosił w kościele św. Floriana w Krakowie kilka konferencji zatytułowanych Rozważania o istocie człowieka, które zostały wydane z manuskryptu dopiero po prawie pięćdziesięciu latach od ich powstania [Wojtyła 1999].

Ważnym tematem tych rozważań jest pytanie o odrębność natury człowieka, którą Wojtyła widzi przede wszystkim w świadomości. Uznaje ją za przejaw „ducha ludzkiego” i rozumie pod tym pojęciem „odrębny byt, odrębny ustrój i odrębną od materii wewnętrznie i istotowo niezależną organizację, której w żaden sposób nie można wyprowadzić z materialnego podłoża ani z nim utożsamić" [Wojtyła 1999: 22]. Myślicielowi chodzi tu o taki wymiar czynów i przeżyć człowieka, które świadczą o samej jego istocie; należą do nich zdolności kulturotwórcze osoby, ludzka myśl i wola czy twórczość, a także akty poznania.

Wojtyła [1999: 96] - podobnie jak Frankl - uważa, że bycie osobą wiąże się bezpośrednio z życiem duchowym i duchowością: "Osobą może być tylko byt duchowy, bo tylko na kanwie duchowości daje się pojąć świadomość, zwłaszcza samoświadomość i wolność. One zaś obie warunkują odpowiedzialność. Wszystkie zaś owe rysy stanowią przejawy życia i bytu osobowego". Oczywiście filozof nie ogranicza osoby wyłącznie do duchowości, nazywając ją dalej bytem psychofizycznym, ale podkreśla wagę „niepowtarzalnej treści ludzkiego ducha" tworzącego unikatowość danej osoby i wyrażającego ją. Tej właśnie treści warto szukać w badaniu biograficznym, pozwala ona bowiem sięgnąć do samej głębi ludzkiej egzystencji, a tym samym przedstawić jednostkę w jej najbardziej szczególnym aspekcie, niepowtarzalnym i niemożliwym do zredukowania. Jak pisze dalej Wojtyła [1999: 97], ów rys powoduje, że „każdy człowiek, aczkolwiek mieści się w granicach ludzkiego gatunku, to jednak równocześnie występuje poniekąd z tych granic, aby stanowić każdy dla siebie odrębny świat przeżyć, twórczości i celów”.

Bartnik [2006, 2012] podkreśla, że osoba nie tylko jest przedmiotem, ale przede wszystkim podmiotem poznania oraz działa- 
nia, egzystuje wielowymiarowo: w płaszczyźnie ciała (które daje jej realność, historyczność, doczesność) i równocześnie w płaszczyźnie duszy (jako byt niezłożony, transcendentny, duchowy, podmiotowy) [Bartnik 2006: 23-24]. Podstawowymi cechami człowieka jako osoby są: cielesność, rozumność, dążeniowość i działalność [Bartnik 2012: 39].

W personalizmie rozumianym systemowo osoba stanowi centrum bytu i odkrywa siebie w myśleniu, świadomości, rozumie, zdolnościach poznawczych, czynie, działalności czy twórczości: „Człowiek doświadcza siebie następnie na niepojętych obszarach woli, miłości, dążeń, planów, marzeń i wielkiej nostalgii za istnieniem, dobrem, doskonałością, świętością, niezwykłością" [Bartnik 2006: 32]. Personalistyczny obraz osoby jako jednostki wolnej, „niewyczerpalnej treściowo i tematycznie”, skupia się na życiu podmiotowym, które ,jest jakąś głębią bez dna i bez granic” [Bartnik 2006: 32]. Dlatego też do podstawowych struktur świata osoby należą: immanencja życia, twórczość, bytowanie indywidualne i społeczne, moralność oraz relacja do Boga osobowego [Bartnik 2012: 43-47, 50].

Ciekawą próbą spojrzenia na personalizm z perspektywy współczesnej jest sformułowane przez Jana Galarowicza [2009] Moje credo antropologiczne, zainspirowane prowadzonymi przez wiele lat badaniami nad personalizmem obecnym w myśli Romana Ingardena, Wojtyły oraz Józefa Tischnera. Według Galarowicza najważniejsze pytanie stawiane sobie przez człowieka brzmi: „kim jestem”. Filozof próbuje odpowiedzieć na nie całościowo, odwołując się do filozofii bytu, filozofii świadomościowo-przeżyciowej oraz filozofii dialogu i agatologii. Swoje idee formułuje w wyraźnej kontrze do „ponowoczesnej filozofii słabej”, którą oskarża o redukcjonizm i animalizację człowieka, a całość traktuje jako odpowiedź na zaatakowanie „egologicznej struktury osoby ludzkiej”, dlatego też jego koncepcja wydaje się nadzwyczaj dobrze wyrażać konkurencyjny wobec poststrukturalistycznego model biografii.

Galarowicz [2009: 437-456] pisze, iż osoba jest bytem realnym, który doświadcza swej realności, odczuwa też różnicę między sobą a innymi bytami (nieożywionymi, roślinami i zwięrzętami); jest to różnica wynikająca z doświadczenia realności osobowej, czyli 
tego, co jest w człowieku nieredukowalne. Osoba przeżywa siebie jako „ja” (czyli na sposób egologiczny), posiada zatem centrum złożone z somatyki (ciało), psychiki oraz ducha (tworzą go: świadomość, wolność, samostanowienie, wola, rozum i serce); rdzeniem tego osobowego centrum jest „jaźń”. Równocześnie osoba jest bytem relacyjnym, dialogicznym i komunijnym: „Komunijny charakter osoby to coś głębszego niż otwartość człowieka na inne osoby, życie z nimi i działanie razem z nimi” - pisze Galarowicz [2009: 452]. Polega na adekwatnym potraktowaniu innego jako bliźniego, afirmacji jego człowieczeństwa i wzięciu za niego odpowiedzialności (czasem nawet $\mathrm{w}$ formie poświęcenia się dla niego).

Osoba w naturalny sposób odczuwa zatem swoją wartość (jako godność), także wartość innych ludzi oraz świat wartości jako takich (jako Tischnerowskie ,ja aksjologiczne”):

Więź człowieka z wartościami ma wieloraki charakter: człowiek odczuwa i poznaje wartości, jest przez nie poruszony i ulega ich urokowi, odpowiada na nie, wciela je w życie, a wcielając je, buduje siebie jako istotę aksjologiczną. [Galarowicz 2009: 448]

Szczególny wyraz godności jako odpowiedniego odniesienia się do osoby ze względu na to, kim jest, stanowi norma personalistyczna [Galarowicz 2009: 448-449]. Jest wyrazem tego, że w modelu personalistycznym biografii narracyjna reprezentacja życia mieści w swoim centrum człowieka i jego historię życia, badaną dla niego samego i z poszanowaniem jego godności ${ }^{12}$.

\section{Biografia a norma personalistyczna}

Tak zwana norma personalistyczna nie dopuszcza traktowania osoby inaczej niż jako celu samego w sobie [Wojtyła 1986; Krajew-

12 Nie oznacza to jakichkolwiek zafałszowań czy cenzury w badaniach biograficznych, a wręcz odwrotnie - poszukiwanie jak najpełniejszej i dobrze uzasadnionej prawdy o człowieku i jego życiu właśnie w imię jego godności. Odniesienie do prawdy jako do wartości podstawowej stanowi jeden z wyznaczników personalizmu w ujęciu i Wojtyły [1969, 1986, 1999], i Stycznia [2001], i Galarowicza [2009]. 
ski 2001; Ozorowski 2004; Jędraszewski 2009; Gacka 2014; Zabielski 2014; Drożdż 2016; Kunicka 2017]. Norma personalistyczna określa sposób odniesienia do osoby, który wynika z tego, kim ona jest, i polega na afirmowaniu osoby dla niej samej [Styczeń 2001]. Jak pisze Wojtyła [1986] w jednej z kluczowych dla jego antropologii prac - Miłość i odpowiedzialność - człowiek jako osoba jest takim dobrem, iż jedynym właściwym i pełnowartościowym sposobem odniesienia do niego jest miłość [Wojtyła 1986] ${ }^{13}$.

Miłość jako najbardziej sprawiedliwy i słuszny sposób odnoszenia się osoby do osoby definiowana jest przez Wojtyłę [1986: 43-44] tak:

[...] miłość osoby musi polegać na afirmowaniu jej ponad-rzeczowej i ponad-konsumpcyjnej (ponad-użytkowej) wartości. [...] Właśnie tutaj podstawowym zadaniem jest wypracowanie pojęcia miłości sprawiedliwej dla osoby, czyli miłości gotowej zawsze oddać każdemu człowiekowi to, co mu się słusznie należy z tej racji, że jest osobą.

Miłość ta, przyjmująca w akcie pisania biografii postać życzliwości i szacunku, nie przekreśla dążenia do prawdy i rzetelności w opracowywaniu faktów. Wyznacza wysokie wymagania etyczne wynikające wprost zarówno z imperatywu kategorycznego Immanuela Kanta (osoba ludzka jako cel sam w sobie - a nigdy środek do celu), jak i jej rozwinięcia oraz dopełnienia, którym jest norma personalistyczna [Gacka 2014].

Józef Zabielski [2014: 125-126] pisze o zakresie działania normy personalistycznej w następujący sposób:

Traktowanie osoby ludzkiej jako celu działania, a nie środka do celu stanowi fundamentalne założenie personalistycznej koncepcji wyjaśnienia natury ludzkiej. Jej normatywna treść sprowadza się do prawdy, że wartość człowieka - jako osoby -

13 Pierwsze wydanie tej rozprawy ukazało się w roku 1960 (tutaj cytowana jest czwarta edycja), a zatem siedem lat przed pracą Osoba i czyn, w której Wojtyła [1969] definiuje osobę w działaniu jako podmiot etyczny. 
jest podstawą powinności etycznej. W godności osobowego bytu ludzkiego zakotwiczony jest wymóg uznania i respektowania każdego człowieka. Każdemu człowiekowi jako osobie należna jest afirmacja ze strony innej osoby. Rozumienie wartościującej godności człowieka rodzi konkretne powinności: uszanowanie autonomiczności bytu osobowego i wartości życia, zobowiązanie do działania „w polu odpowiedzialności”, respektowanie dobra konkretnych osób oraz całej społeczności ludzkiej.

Przypomina również obecne od starożytności w kulturze stwierdzenia afirmujące osobę, takie jak Homo homini res sacra („Człowiek człowiekowi jest świętością”), Homo homini summum bonum („Człowiek człowiekowi jest najwyższym dobrem”) czy Persona humana est affirmanda propter se ipsum („Osobę ludzką należy afirmować ze względu na nią samą").

"Osoba i jej transcendencja stoją u początku etyki” - zauważa z kolei Michał Drożdż [2016], wskazując sposoby oddziaływania normy personalistycznej jako zasady regulującej uznanie godności osoby. Pierwszy sposób obejmuje samą jednostkę, „ponieważ człowiek jako podmiot działający doświadcza fundamentów swojego działania, doświadcza swojej racjonalności i wolności” [Drożdż 2016: 14]. To doświadczenie stanowi podstawę drugiego sposobu oddziaływania normy personalistycznej - odniesienia do innego: "Człowiek jako osoba jest również drogą respektowania godności każdej innej osoby. W tym sensie także staje się zasadą etycznego wartościowania” [Drożdż 2016: 14].

Oczywiście obszar oddziaływania normy personalistycznej jest bardzo szeroki i daleko wykraczający poza problem biografii. Tym niemniej wydaje się, że odniesienie do niej w modelu personalistycznym może stanowić podstawę etyki pracy biografa ze względu na szczególny charakter jego tekstu, symboliczną rolę i relację, w którą wchodzi. Gdy staje się - przykładowo - „biografem Adama Mickiewicza”, wchodzi w relację osobową, a nie w podmiotowo-przedmiotową. Biograf, reprezentując twórcę, którego portret przybliża odbiorcy, staje się zatem kimś, kto symbolicznie działa w imieniu twórcy, przekształca swój głos (nar- 
racyjny) w jego głos: jako autor narracji biograficznej tworzy za pomocą biografii reprezentację ontologiczną, która zastępuje pierwowzór (niedostępnego dla czytelnika twórcę) wytworzonym obrazem: biografią. Zadanie biografa wykracza zatem poza kulturowo zdefiniowaną rolę pisarza, kształtuje bowiem obraz twórcy w szerokiej świadomości społecznej, gdyż za sprawą paktu biograficznego tekst odbierany jest przez czytelników jako prawdziwy i wiarygodny.

Norma personalistyczna w jeszcze jednym aspekcie reguluje aktywność biografa - redukuje tendencję do oceniania czy wydawania sądów, promując raczej empatię, postawę rozumiejącą, dociekanie najgłębszych motywacji podejmowanych przez bohatera biografii działań i poszukiwanie mechanizmów wyjaśniających jego postępowanie. Hamuje w ten sposób naturalną skłonność do wartościowania czynów i wyborów, gdyż respektuje wartość osoby dla niej samej, niezależnie od jej historii życia.

Norma personalistyczna bowiem nie wywodzi się z biologicznej wartości życia, lecz odwrotnie: to osoba swoim istnieniem sprawia, że jej życie biologiczne, psychiczne, itp. jest wartościowe. W tym wymiarze wartość istnienia osoby, wartość ludzkiego życia, nie może być przedmiotem uzgodnień czy społecznego konsensusu, nie może też być nadawana czy odbierana przez decyzje ekspertów [...]. [Zabielski 2014: 131-132]

Osoba jest bowiem w personalizmie definiowana jako

wszechświat o naturze duchowej, obdarzony wolnością wyboru i stanowiący tym samym całość niezależną od świata. Ani natura, ani państwo nie mają dostępu do tego wszechświata bez pozwolenia. [Maritain 1960: 16]

Z samego bycia osobą wynika jej godność oraz podmiotowość przejawiająca się najpełniej w sprawczości i świadomym działaniu [Kunicka 2017]. Tę godność biograf zobowiązany jest szanować, 
gdy podejmuje się rekonstruowania biegu życia osoby, jaką jest twórca.

Odpowiedzialność wypływająca z normy personalistycznej staje zatem u początku każdej biografii pisanej w proponowanym tu ujęciu personalistycznym. Rekonstruowanie rozwoju osoby w biegu jej egzystencji zakłada wszak określoną antropologię, a proces poznawania i opisywania historii życia poprzedza próba jego zrozumienia i konceptualizacji. Wymaga to rozpoznania człowieka jako osoby - jej godności i wartości - w każdym akcie poznawczym składającym się na proces powstawania biografii:

Byt osobowy stanowi punkt wyjścia w rozumieniu człowieka, a nie punkt dojścia egzystencjalnego faktu istnienia osoby. Takie rozpoznanie człowieka stawia go w pozycji wyjątkowej jako tego, który jest przedmiotem poznania i doświadczenia oraz oddziaływania, zarówno wewnętrznego, jak i zewnętrznego. [Zabielski 2014: 131]

Wyjątkowość osoby jako przedmiotu badania jest więc czymś zasadniczym i mającym wpływ na wszystkie inne działania autora biografii. Norma personalistyczna, o której Zabielski pisze, że jest „zakotwiczona w naturze osobowego bytu człowieka", jako zasada normująca (norma normans) poprzedza wszystkie inne zasady, również te odnoszące się do pisania biografii, gdyż „ukazuje, że to osoba jest podstawą ludzkich zachowań moralnych, a nie jakaś bezosobowa rzeczywistość, jak np. nakazy prawa czy normy społeczno-obyczajowe" [Zabielski 2014: 131]. Obowiązuje również $\mathrm{w}$ procesie recepcji biografii, mobilizując do uważnej lektury, dyskusji i polemik w imię prawdy wówczas, gdy czyjaś historia życia zostaje zniekształcona czy nawet zakłamana:

Dobro osoby - każdej osoby - jest i powinno być dla każdego najważniejsze. W tym kontekście oczywiste staje się to, że w myśl zasady personalistycznej zamieszczanie jakichkolwiek nieprawdziwych lub demoralizujących informacji $[\ldots]$ jest czymś moralnie złym. [Jędraszewski 2009: 315] 
Sprzeciw wobec tej sytuacji jest znakiem solidarności w sferze etyki ${ }^{14} \mathrm{i}$ równocześnie wyrazem rzetelności badawczej obowiązującej każdego naukowca, nie tylko w biografistyce.

Zatem w procesie pisania biografa i bohatera jego opowieści łączy relacja biograficzna, która ma charakter osobowy, a nie podmiotowo-przedmiotowy. Przekracza czas i miejsce, sytuując się w przestrzeni symbolicznej, regulowana jest paktem biograficznym, na mocy którego biograf zyskuje szczególne prawo: tworzy autorski obraz biegu życia. To za jego pośrednictwem społeczeństwo poznaje twórcę i na bieżąco rewiduje jego pozycję w panteonie historii, uwzględniając nie tylko jego dorobek, ale również to, kim był i w jaki sposób przeżył swoje życie, jakich wyborów dokonywał i co je motywowało.

W modelu personalistycznym biografii doświadczanie własnego człowieczeństwa i akceptacja podmiotowości innego, także tego, którego bieg życia się rekonstruuje, to podstawa rzetelnej naukowo i sprawiedliwej, podążającej ku prawdzie biografii. Norma personalistyczna jako zasada stojąca u fundamentów pracy biografa odwołuje się do postawy szacunku dla jedynego i niepowtarzalnego „ja” jako podmiotu własnego istnienia i działania. Podmiotowość człowieka gwarantuje jego tożsamość, sięga do samych podstaw jego bytowania, ukazuje go w całym bogactwie jego istnienia [Zabielski 2014]. Biografia bez tej perspektywy, skupiona na zewnętrznych faktach i zdarzeniach, zniekształca tworzoną reprezentację w sposób systematyczny i nieodwracalny, gdyż nie uwzględnia bytowania człowieka jako osoby, a ten aspekt w biografii personalistycznej stanowi jej zasadniczą cechę. Badacz biografii

Marek Jędraszewski [2009] przywołuje w tym miejscu Osobę i czyn Wojtyły oraz podział na postawę autentyczną i nieautentyczną. Wyrazem autentyczności w sytuacji zakłamywania czy fałszowania faktów jest solidarność i sprzeciw, wyrazem nieautentyczności - konformizm i unik. Wydaje się, że dziś nazbyt często w biografistyce akceptuje się prace dalekie od badawczej rzetelności i preferujące słabo udokumentowane spekulacje zamiast rzeczowych, potwierdzonych w źródłach faktów - w imię pluralizmu, swobody wypowiedzi czy prawa do własnej interpretacji danych. Poświęca się tym samym dobro jednej osoby (bohatera biografii - często jego dobre imię i godność) w imię dobra drugiej - autora; właśnie na to nie pozwala norma personalistyczna i przed tym chroni obie strony relacji biograficznej. 
tu postulowanej respektuje osobę bohatera biografii, co wyraża się w konkretnym podejściu teoretycznym i metodologicznym, którego wyznacznikiem jest Dziesięć tez na temat osoby Frankla [2017].

\section{Podmiotowy charakter wiedzy o sobie}

\section{w biografii personalistycznej}

Charlotte Bühler [1999], postulująca uwzględnienie w analizie biegu życia danych subiektywnych na równi z danymi obiektywnymi, stała się prekursorką podejścia, którego podstawą jest upodmiotowienie bohatera biografii. Aby tego dokonać, biograf musi podzielić się symboliczną władzą nad tworzoną przez siebie reprezentacją. Czyni to, dopuszczając do głosu postać, o której pisze.

Oddanie głosu w biografii jej bohaterowi nie opiera się jednak na prostym wykorzystaniu w narracji fragmentów autobiograficznych (korespondencji, dzienników czy pamiętników), ale idzie o wiele głębiej. Polega bowiem na świadomym usunięciu w cień prymatu narracji obiektywizującej i uprzedmiotawiającej na rzecz równoprawnego potraktowania - jako współkonstytuujących dyskurs - wypowiedzi bohatera biografii. Jego historia życia nie może się przecież składać wyłącznie z faktów oraz wydarzeń, gdyż to, co najbardziej pasjonuje czytelników biografii, wynika z jej osobowego, subiektywnego charakteru, z udostępnienia szerszej publiczności wewnętrznego, podmiotowego punktu widzenia, który na zasadzie podmiotowej sygnatury odciska się w każdym akcie postrzegania, zarówno siebie, jak i świata: „Człowiek nigdy nie doświadcza czegoś poza sobą, nie doświadczając w jakiś sposób siebie w tym doświadczeniu" [Wojtyła 1969: 5]. Zewnętrzny, przedmiotowy opis tego "doświadczania siebie” nigdy nie jest w stanie zastąpić podmiotowej, autorskiej relacji, gdyż - jak pisze dalej Wojtyła [1969: 8] w rozprawie filozoficznej Osoba i czyn:

[...] człowiek o wiele bardziej i o wiele inaczej jest dany sobie samemu, a więc jako własne „ja”, aniżeli jako każdy inny człowiek, który nie jest mną. [...] Bywa tak, że przy wielkim zbliżeniu do drugiego człowieka łatwiej nam o obiektywizację tego, co jest w nim, czy też tego, kim on jest, ale obiektywizacja 
to nie to samo co doświadczenie. Przedmiotem doświadczenia jest każdy dla siebie samego w sposób jedyny i niepowtarzalny i żaden stosunek z zewnątrz do żadnego innego człowieka nie może być podstawiony na miejsce tego stosunku doświadczalnego, jaki jest udziałem własnego podmiotu.

Tę niezbywalną specyfikę spojrzenia „z perspektywy pierwszej osoby" opisuje również - w kontekście filozofii umysłu John R. Searle [1999ab]. Według niego świadomość podmiotu można poznać wyłącznie z subiektywnej perspektywy: „Każdy stan świadomy jest zawsze czyimś stanem świadomym” [Searle 1999b: 135], a w dodatku „Świat jako taki nie ma własnego punktu widzenia, ale dostęp, jaki mam do świata za pośrednictwem moich stanów świadomych, jest zawsze dostępem z pewnej perspektywy, z mojego punktu widzenia” [Searle 1999b: 135-136]. W biografii to osobowe, subiektywne spojrzenie jest równie interesujące jak ujęcie biografa, obiektywizujące i zewnętrzne. Jest ono też od niego całkowicie odmienne: „[...] w ujęciu epistemicznym punkt widzenia pierwszej osoby różni się zasadniczo od punktu widzenia trzeciej osoby" - pisze Searle [1999b: 102].

Podobnie, choć wychodząc z innych założeń, kwestię tę widzi Wojtyła. Wskazuje na zróżnicowanie „wewnętrzności” i „zewnętrzności” - doświadczenie tej różnicy jest dane zarówno samej jednostce, jak i zewnętrznemu wobec niej obserwatorowi:

Tak więc przede wszystkim ja sam dla siebie jestem nie tylko „wewnętrznością”, ale także „zewnętrznością”, pozostając przedmiotem obu doświadczeń, i od wewnątrz, i od zewnątrz. Każdy zaś inny człowiek poza mną, chociaż jest dla mnie tylko przedmiotem doświadczenia od zewnątrz, nie stoi jednak wobec całokształtu mojego poznania jako sama „zewnętrzność”, ale ma również właściwe sobie wnętrze. Chociaż wprost nie doświadczam tego wnętrza, jednak o nim wiem. [Wojtyła 1969: 10]

Ta różnica perspektyw ujawnia się szczególnie wyraziście w przypadku prób opisu wewnętrznego świata podmiotu: opis ten nie jest możliwy z perspektywy zewnętrznej, trzecioosobowej: 
Perspektywa trzeciej osoby, właściwa tej epistemologii, nie powinna przesłaniać nam jednak faktu, że właściwa ontologia stanów mentalnych jest ontologią z perspektywy pierwszej osoby. [...] tracimy z pola widzenia podstawową własność zjawisk mentalnych, mianowicie to, że ich ontologia jest zasadniczo ontologią z perspektywy pierwszej osoby. Przekonania, pragnienia itd. są zawsze czyimiś przekonaniami i pragnieniami i są zawsze potencjalnie świadome, nawet wtedy, gdy faktycznie pozostają nieświadome. [Searle 1999b: 34-35]

Do kwestii tej badacz wielokrotnie w swej książce powraca, pisząc dalej chociażby tak:

Skoro zjawiska mentalne są nieodłącznie związane ze świadomością, a świadomość ma w rzeczywistości subiektywną naturę, wypływa z tego wniosek, że ontologia tego, co mentalne, jest zasadniczo ontologią z punktu widzenia pierwszej osoby. Stany mentalne są zawsze czyimiś stanami mentalnymi. Istnieje zawsze jakaś „pierwsza osoba”, jakieś ,ja”, które posiada owe stany mentalne. Dla naszych rozważań ważne okazuje się więc to, że punkt widzenia pierwszej osoby jest pierwotny. [Searle 1999b: 39-40]

Zwłaszcza ostatnia uwaga ma niezwykle doniosłe znaczenie: jeśli pierwotny w przypadku opisów świata mentalnego jest właśnie pierwszoosobowy, podmiotowy punkt widzenia, to nie da się pomyśleć rzetelnej i oddającej sprawiedliwość biografii, która byłaby go pozbawiona.

W biografii współobecność głosu bohatera, traktowanego jako równoważny w stosunku do głosu narratora, wynika zatem ze specyfiki opowieści o życiu, którego niezbywalnym elementem jest świat wewnętrznych przeżyć i doświadczeń podmiotu. Rezygnacja z niego, nawet w imię większego obiektywizmu, prowadzi nieuchronnie do redukcjonizmu, zniekształcając powstającą historię życia. Wskazuje na to Searle [1999b: 38] w odniesieniu do naukowych prób opisu świadomości i ludzkiego umysłu: „Ontologia stanów mentalnych jest na ogół nieredukowalnie subiek- 
tywna [...]”. Zauważa, iż ideał obiektywności w badaniu świata wewnętrznego, prowadzący do formułowania koncepcji umysłu (świadomości) z punktu widzenia trzeciej osoby, jest błędny. Pisze o tym następująco:

W ramach owej tradycji próbuje się badać umysł w taki sposób, jak gdyby składał się on z neutralnych zjawisk, niezależnych od świadomości i subiektywności. Podejście takie nie uwzględnia jednak najistotniejszych własności, które odróżniają zjawiska mentalne od zjawisk pozamentalnych. [...] Najbardziej niedorzeczne są jednak próby rozpatrywania samej świadomości w oderwaniu od świadomości, to znaczy wyłącznie z punktu widzenia trzeciej osoby, co prowadzi do poglądu, że świadomości jako takiej, rozumianej jako „wewnętrzne”, „prywatne” zjawiska, nie przysługuje realne istnienie. [Searle 1999b: 38-39] $]^{15}$

Opisywanie wewnętrznego świata podmiotu za pomocą zewnętrznej, trzecioosobowej narracji i kategorii nieuwzględniających subiektywności jako istotnej i jedynej perspektywy pozwalającej ująć zjawiska mentalne prowadzi nieuchronnie do redukcjonizmu, a nawet - w skrajnej postaci - do zanegowania stanów podmiotu niedających się zobiektywizować. Wspomina o tym również Antonio R. Damasio [2000: 92], badacz zajmujący się filozofią umysłu z perspektywy neuropsychologicznej: „Czy to się komuś podoba, czy nie, cała zawartość naszego umysłu jest subiektywna, siła nauki zaś leży w zdolności do obiektywnej weryfikacji zgodności wielu jednostkowych subiektywności”. Wskazuje przy tym, iż istota problemu nie tkwi w samej subiektywności, lecz w naturalnej dla człowieka postawie wnioskowania o wewnętrznych stanach innych na podstawie własnych doświadczeń. Jest to jednak równocześnie droga do przezwyciężenia owej prywatności ujęcia i uzyskania intersubiektywnego, a zatem ponadjednostkowego spojrzenia: 
Rozwiązanie problemu metodologicznego powstałego za sprawą osobistego (prywatnego) charakteru świadomości zasadza się na naturalnej zdolności człowieka do stałego teoretyzowania na temat stanu umysłu innych osób na podstawie obserwacji ich zachowań, informacji o stanie ich umysłów oraz na podstawie weryfikacji ich wzajemnych zależności przy założeniu, że sam obserwator ma porównywalne doświadczenia. [Damasio 2000: 92]

Nie ma zatem innej możliwości niż „oddanie głosu” bohaterowi biografii tak, by mógł sam opowiedzieć o swoim świecie wewnętrznych przeżyć. Słów własnych twórcy nie da się zastąpić parafrazującą narracją biografa, gdyż ów „cudzy głos” zniekształca pierwotną wypowiedź i podporządkowuje ją nadrzędnemu konceptowi autora, uprzywilejowując zewnętrzną, trzecioosobową perspektywę. Norma personalistyczna - w praktycznym wymiarze - zachęca do przyznania odpowiedniego, należnego osobie miejsca w opowieści o jej własnym życiu. Relacja biograficzna jest bowiem dialogiem i spotkaniem, a nie areną walk o symboliczną władzę nad dyskursem ${ }^{16}$.

W modelu personalistycznym biograf, przy całej świadomości podejścia przedmiotowego, koniecznego w badaniach naukowych właśnie ze względu na wyjątkowy charakter i rolę tworzonej przez siebie biografii, respektując podmiotowość jej bohatera, powinien w jak najszerszym wymiarze dopuścić go do głosu. Oznacza to jednak, że w obręb narracji wprowadza tekst cudzy, i to o szczególnym statusie, cechach gatunkowych oraz odmienności wynikającej z określonej sytuacji komunikacyjnej. Takim tekstem jest właśnie list ${ }^{17}$.

Na marginesie warto zauważyć, że innym, równie ważnym miejscem spotkania (a czasem terenem walk i sporów) jest archiwum pisarza i jego losy; w ostatnim czasie bardzo ciekawie pisała o tym w odniesieniu do Kazimiery Iłłakowiczówny Lucyna Marzec [2018].

17 Temat listu jest sam w sobie na tyle rozległy, że nie sposób omówić go w tym miejscu szerzej, zwłaszcza jeśli chodzi o ciąg kwestii szczegółowych (takie jak: list genologicznie, list jako źródło historyczne, świadectwo biograficzne, tekst kultury, zapisana rozmowa) oraz metodologię badań nad nim. Próbę jego definicji, 


\section{List jako szczególny wyraz podmiotowości w biografii}

Wprowadzenie listów do narracji biograficznej tylko pozornie wydaje się zadaniem łatwym. Korespondencja jest materiałem trudnym dla badacza jako źródłowo niejednorodna, narzucająca swój pierwotny komunikacyjny i dialogowy charakter, pisana z pierwszoosobowej perspektywy, rozbijająca jedność narracji badacza. Każda z tych cech sprawia, że rodzi się pokusa, by ten „własny głos” bohatera biografii podporządkować dyskursywnej ramie, cytując listy w krótkich fragmentach, wykrawając z nich „zdania użyteczne”, najczęściej wyłącznie te, które potwierdzają tezy biografa. List tak używany staje się przestrzenią nadużyć - aż do cenzury włącznie - a równocześnie sam ulega rozwarstwieniu i fragmentacji.

O niewłaściwym używaniu korespondencji pisze bardzo trafnie Zbigniew Majchrowski w odniesieniu do listów autora Pana Tadeusza: „Korespondencja Mickiewicza została skolonizowana w toku lektury źródłowej: listy traktowano jako klocki konstrukcji biograficznych" - wskazuje badacz. Wymienia (jako przykłady) książki Jarosława Marka Rymkiewicza czy Kronikę życia i twórczości Adama Mickiewicza. W konkluzji zaznacza jednak powszechność dyskusyjnych praktyk prowadzących do uprzedmiotowienia listów:

[...] udział $\mathrm{w}$ tym procederze mają właściwie wszyscy przedstawiciele mickiewiczologii. Jest to praktyka oczywista i powszechna w badaniach historycznoliterackich, $\mathrm{w}$ biografistyce, w tekstologii. Rzecz w tym, że w przypadku Mickiewicza są to operacje wyjątkowo wyniszczające źródło. [Majchrowski 2014: 15]

W dalszej części badacz wymienia różne kontrowersyjne działania, takie jak: rozbijanie listu na krótkie fragmenty (a nawet

omówienie cech gatunkowych czy tematów pokrewnych (takich jak autokreacja, komunikacyjność czy metatekstualność) zawarłam w osobnym artykule, który ukaże się niebawem [Całek 2019a]. Obszerne omówienie problematyki korespondencji pod kątem teoretycznym zamieściłam w monografii Nowa teoria listu [Całek 2019b]. 
pojedyncze zdania), zawłaszczenie narracyjne, parafrazowanie. Wszystko to prowadzi do uczynienia z korespondencji wyłącznie „bazy danych”, a dodatkowo hierarchizuje treść, dzieląc pierwotnie logiczną i spójną całość listu na rozdrobnione dane ważne i nieważne.

Owa reszta [pisze dalej Majchrowski - A.C.] to często obraz egzystencji, której nie można unieważnić, tymczasem jedynie mały urywek urasta do rangi znaczącego wydarzenia i pomniejsza to, co stanowi większą część listowego zapisu. [Majchrowski 2014: 18-19]

Prosty gest cytowania jest zatem w rzeczywistości działaniem nieoczywistym, wymagającym namysłu i świadomości metodologicznej, gdyż bardzo łatwo jest zawłaszczyć cudze słowo i podporządkować własnemu, wykorzystać jako środek do celu, a nie cel sam w sobie. Ale dzieje się też odwrotnie: wypowiedź twórcy zacytowana w odpowiedni sposób przywraca mu podmiotowość w narracji i czyni z niego równorzędnego partnera relacji biograficznej, co ma w tym przypadku zasadnicze znaczenie i wagę, zarówno w wymiarze epistemologicznym (możliwość dostępu do wewnętrznego świata twórcy), jak i etycznym (realizacja normy personalistycznej).

Personalistyczny model biografii wymaga zatem i w tym aspekcie pogłębionej refleksji oraz przestrzegania zasady respektowania integralności i specyfiki źródła: aby list stał się wyrazem podmiotowości w biografii, nie wystarczy przeplatanie własnej narracji odpowiednio dobranymi cytatami. Oddać głos - to uszanować bohatera biografii jako osobę i z tego powodu ustąpić mu miejsca w tych kwestiach, które dotyczą jego wewnętrznego świata. Dopuszczenie go naprawdę do głosu oznacza w praktyce oddanie władzy nad narracją tam, gdzie samoograniczenie biografa pozwala równocześnie na szersze i mocniej zakorzenione w wypowiedziach bohatera zaprezentowanie myśli, emocji oraz jego własnego doświadczania siebie i świata.

Wyrażane przez podmiot epistolarny oceny, opinie czy wyznania mogą nawet stać $\mathrm{w}$ sprzeczności z obiektywnie ustalonymi 
faktami, ale wówczas tym bardziej odsłaniają prawdę o bohaterze biografii dzięki możliwości skonfrontowania różnych punktów widzenia i relacji. Poddane analizie stają się natomiast doskonałym źródłem informacji na temat jego świata wewnętrznego: postaw, przekonań, konfliktów, reakcji na wartości. Zafałszowanie, autoprezentacja, selektywność, przemilczenia czy tendencyjny sposób relacjonowania wydarzeń nieraz mówią więcej o twórcy niż komentarze jego biografa, a ich zderzenie $\mathrm{z}$ danymi obiektywnymi niesie samo w sobie niezwykle cenne dla badacza i odbiorcy informacje. W liście najważniejsza i równocześnie najbardziej interesująca jest właśnie prawda podmiotu: jego wewnętrzna prawda istnienia oraz prawda ukryta $\mathrm{w}$ jego sposobie patrzenia na rzeczywistość. Nie da się jej niczym zastąpić i nie można jej bez zniekształceń sparafrazować. Tylko w pierwotnym kształcie list stanowi bowiem punkt dostępu do osoby, która go napisała, oraz do dialogu epistolarnego, który rozegrał się na przestrzeni tekstu między nadawcą listu a jego adresatem [por. Całek 2019b]. Jest zatem najbardziej osobowym i równocześnie osobistym w charakterze sposobem ekspresji własnej podmiotowości wykorzystywanym w narracji biograficznej.

Na list warto jeszcze spojrzeć z perspektywy omawianych powyżej Dziesięciu tez na temat osoby Frankla [2017]. List, postrzegany jako rezultat osobowego, podmiotowego działania, staje się formą ekspresji osoby i jej podstawowych cech (jedności, całościowości, godności, duchowości, dynamiki, jednostkowości jakże odmiennych od tych, które na czele stawiają reprezentanci nurtu ponowoczesnego), a równocześnie stanowi narzędzie transcendencji czynionej w obecności Innego i jest miejscem wypróbowywania swoich możliwości (tworzy przestrzeń kreacji Siebie i praktykowania Siebie [por. Całek 2019b]). Wszystko to osoba czyni, realizując wolę sensu [Frankl 2017], nieustannie poszukiwanego w duchu odpowiedzialności za siebie.

Podsumowując powyższe rozważania na temat ekspresji podmiotowości w biografii, którą umożliwia przyjęcie antropologii perso- 
nalistycznej jako fundamentalnej koncepcji człowieka, kształtującej teoretyczne i metodologiczne podstawy narracji biograficznej [por. Całek 2013], warto jeszcze na chwilę powrócić do wspominanej na początku dwutorowości refleksji nad podmiotem.

Współczesne teorie biografii, analizowane z punktu widzenia ich podstaw teoretycznych i koncepcji antropologicznych, do których się odnoszą, sytuują się zasadniczo w dwóch głównych nurtach badawczych. Nurt ponowoczesny odwołuje się do rozmaitych koncepcji: postmodernizmu, dekonstrukcji, psychoanalizy (zwłaszcza lacanowskiej), socjologii, feminizmu i teorii queer; ich wspólną podstawa są antropologie redukcjonistyczne. Rezygnacja z mocnego podmiotu na rzecz nieustannie konstytuującego się, zmiennokształtnego „podmiotu słabego”, który nie poznaje rzeczywistości, ale wciąż ją wytwarza, odrzucenie podziału na fikcję i prawdę (zgodnie z przyjętym jako zasada funkcjonowania podmiotu konstrukcjonizmem), wykorzystywanie chwytów i zabiegów literackich, dopuszczenie literaturyzacji jako nieuniknionego skutku czasowego i poznawczego dystansu pomiędzy bohaterem biografii a opisującym jego życie badaczem - to główne, charakterystyczne założenia poststrukturalistycznych narracji biograficznych [Całek 2013]. Wyrazem tego podejścia jest również dość liberalne traktowanie materiałów źródłowych, zwłaszcza epistolografii, którą można narracyjnie zawłaszczać, dowolnie selekcjonować, dokonywać radykalnych interpretacji (nieraz wynikających z wyjęcia określonych fragmentów z pierwotnego kontekstu) czy parafrazować. Najdalej idące koncepcje biografii postmodernistycznej całkowicie zacierają granicę między faktami a fikcją, podważając sensowność takiego podziału wobec nieuchronnego konstruktywizmu i tworzenia biografii według modelu powieściowego [Chomiuk 2016; Kraskowska 2019].

Drugim ujęciem - proponowanym tu, a dotąd powszechnie ignorowanym podejściem $\mathrm{w}$ zakresie współczesnych koncepcji podmiotowości, stanowiącym realną alternatywę teoretyczną i metodologiczną dla koncepcji ponowoczesnych - jest nurt personalistyczny wraz z jego antropologią, stawiającą w centrum kwestię osoby. Stanowi on propozycję konkurencyjną w wymiarze filozofii człowieka. Tworzona w tym nurcie biografia będzie respektować 
osobowy charakter egzystencji i wszystkie jej wymiary: cielesny, psychiczny oraz duchowy.

W nurcie personalistycznym, jeśli biografia ma być reprezentacją oddającą sprawiedliwość i twórcy, i światu, w którym przyszło mu egzystować, potrzeba też, by nie zabrakło w niej żadnego z trzech elementów konstytuujących całokształt biegu życia [Bühler 1999; Całek 2013]. Pierwszym jest rekonstrukcja biograficzna pisana z perspektywy zewnętrznej - odwołującej się do obiektywnie lub co najmniej intersubiektywnie dostępnych faktów. Wówczas główna rola przypada biografowi jako temu, który analizuje dane, świadectwa, dokumenty i źródła, aby na tej podstawie zbudować przekonującą całość, która pozwoli czytelnikowi zanurzyć się w świat, jakiego już nie ma. Drugi element stanowi dorobek bohatera biografii w kontekście jego własnej aktywności twórczej i sposobów jej przeżywania (w wymiarze egzystencjalnym i rozwojowym). Trzecim elementem, któremu należy w biografii przyznać odpowiednie miejsce i znaczenie, jest wymiar podmiotowy. W jego centrum stoi korespondencja twórcy: szeroko cytowana, nieokrawana ze „zbędnych” elementów i nieocenzurowana, opatrzona minimalnym komentarzem narratora, którego rolą jest przedstawianie kontekstu danej wypowiedzi, jej pogłębiona interpretacja oraz pełne zrozumienia współmyślenie z twórcą, oznaczające zgodę autora na przyjęcie w siebie jego słów, myśli i emocji.

Tak ujmowany personalistyczny model narracji biograficznej staje w kontrze do szeroko obecnego dziś nurtu ponowoczesnego, a jego obecność jest wyrazem pluralizmu teoretycznego i metodologicznego w humanistyce, która mieści w sobie główny nurt badań biograficznych. Dzięki temu możliwe staje się praktykowanie biografii w innej niż dominująca perspektywie: uwzględniającej istnienie realnego, obiektywnego świata, mocną podmiotowość, która jest zdolna go poznawać, świat wartości, do których człowiek może dążyć, godność osoby wyrażającą się poprzez respektowanie normy personalistycznej oraz poszukiwanie takiej narracji biograficznej, która najwierniej i w najbardziej adekwatny sposób będzie oddawała sprawiedliwość bohaterowi biografii oraz jego czasom. Być może nie jest to perspektywa modna, gdyż mieści się 
poza dominującym nurtem; z pewnością nie jest zgodna z pozytywistycznym mitem obiektywizmu oraz zasadą braku zaangażowania w rzeczywistość badaną (którym hołdował strukturalizm). Wydaje się jednak, że może to być propozycja atrakcyjna badawczo i poznawczo właśnie ze względu na postawienie w centrum zagadnienia osoby (twórcy, bohatera biografii) oraz pytania, kim on był i z czego wynikała unikatowość jego biegu życia. Właśnie ta kwestia, zbieżna z zasadniczym pytaniem człowieka o własną tożsamość i przyszły los, która w biografii staje się opowieścią o życiu Innego i jego znaczeniu, jest jednym z elementów odpowiedzialnych za ponadczasową, niezmienną popularność biografii jako tekstu kultury pomagającego człowiekowi odpowiedzieć na odwieczne pytanie: po co żyje i kim tak naprawdę jest.

\section{Bibliografia}

Ankersmit Frank (2004), Narracja, reprezentacja, doświadczenie. Studia $z$ teorii historiografii, red. Ewa Domańska, Universitas, Kraków.

Bartnik Czesław S., ks. (2006), Szkice do systemu personalizmu, Wydawnictwo KUL, Lublin.

Bartnik Czesław S., ks. (2012), Osoba i personalizm, Standruk, Lublin. Boyer-Weinmann Martine (2005), La Relation biographique. Enjeux contemporains, Éditions Champ Vallon, Seyssel [Francja].

Bühler Charlotte (1999), Bieg życia ludzkiego, przeł. Edward Cichy, Józef Jarosz, Pwn, Warszawa.

Całek Anita (2013), Biografia naukowa: od koncepcji do narracji. Interdyscyplinarność, teorie, metody badawcze, Wydawnictwo Uniwersytetu Jagiellońskiego, Kraków.

Całek Anita (2016a), Biografia jako reprezentacja, „Annales Universitatis Paedagogicae Cracoviensis. Studia Poetica”, vol. 4, s. 25-41.

Całek Anita (2016b), Narrator biografi naukowej: między referencyjnościa a fikcja, w: Przedmiot, źródła i metody badań w biografii, red. Ryszard Skrzyniarz, Lucyna Dziaczkowska, Danuta Opozda, Episteme, Lublin, s. 39-58.

Całek Anita (2017), Czas jako element konstrukcyjny biografi naukowej, w: Czas i miejsca w biografii. Aspekty edukacyjne, red. Elżbieta Dubas, Anna Gutowska, Wydawnictwo Uniwersytetu Łódzkiego, Łódź, S. 21-35. 
Całek Anita (2019a), List jako miejsce ujawniania się wewnętrznego świata twórcy w świetle interakcyjnego modelu badań epistolograficznych, w: Świat wewnątrz nas, t. 1: Ekspresja doświadczenia, red. Agnieszka Gałkowska, Marek Stanisz, Wydawnictwo Uniwersytetu Rzeszowskiego, Rzeszów, s. 73-95 [w druku].

Całek Anita (2019b), Nowa teoria listu, Księgarnia Akademicka, Kraków. Chomiuk Aleksandra (2016), Biomitografie Henryka Sienkiewicza, „Annales Universitatis Paedagogicae Cracoviensis. Studia Poetica”, vol. 4, s. 66-81.

Czarkowski Józef (1994), Oblicza personalizmów. Konfrontacja antropologii filozoficznej E. Mouniera i P. Teilharda de Chardin, Wydawnictwo umk, Toruń.

Damasio Antonio R. (200o), Tajemnica świadomości. Jak ciało i emocje wspóttworza świadomość, przeł. Maciej Karpiński, Rebis, Poznań.

Dosse François (2011), Le pari biographique. Écrire une vie, Éditions La Découverte, Paris [Francja].

Drożdż Michał, ks. (2016), Godność osoby ludzkiej jako fundament i cel komunikacji medialnej, „Studia Socialia Cracoviensia”, nr 2 (15), s. 11-28.

Dybciak Krzysztof (1981), Personalistyczna krytyka literacka. Teoria i opis nurtu z lat trzydziestych, Ossolineum, Wydawnictwo PAN, WrocławWarszawa.

Dybciak Krzysztof (1987), Przedmowa, w: Tymon Terlecki, Krytyka personalistyczna. Egzystencjalizm chrześcijański, Biblioteka „Więzi”, Warszawa, s. 5-19.

Elliott Anthony (2007), Koncepcje „ja”, przeł. Sławomir Królak, Sic!, Warszawa.

Franaszek Andrzej (2019), Przed tajemnica, „Teksty Drugie”, nr 1, s. $240-256$.

Frankl Viktor E. (2017), Dziesięć tez na temat osoby, w: tegoż, Lekarz $i$ dusza. Wprowadzenie do logoterapii i analizy egzystencjalnej, przeł. Roman Skrzypczak, Czarna Owca, Warszawa, s. 259-268.

Gacka Bogumil, MIC (2014), Personalizm chrześcijański Św. Jana Pawła II, „Studia Theologica Varsaviensia”, nr 1, s. 29-58.

Galarowicz Jan (2009), Paradoks egzystencji etycznej. Inspiracje: IngardenWojtyła - Tischner, Wydawnictwo Naukowe PAT, Kraków.

Granat Wincenty, ks. (2018), Personalizm chrześcijański. Teologia osoby ludzkiej, red. Halina Irena Szumił, wyd. 2 popr., Wydawnictwo Diecezjalne, Sandomierz.

Jędraszewski Marek (2009), Konieczność przestrzegania „normy personalistycznej” w społeczeństwie informacyjnym, „Poznańskie Studia Teologiczne", t. 23, s. 309-322. 
Kendall Paul Murray (1965), The Art of Biography, Allen and Unwin, London [Wielka Brytania].

Kowalczyk Stanisław (2014), Z problematyki antropologii personalistycznej, Wydawnictwo KUL, Lublin.

Krajewski Kazimierz (2001), Wprowadzenie. Personalizm etyczny, w: Tadeusz Styczeń, Rozum i wiara wobec pytania: Kim jestem?, Towarzystwo Naukowe KUL, Lublin, s. 7-17.

Kraskowska Ewa (2019), Biografilia. Przypadek Petera Ackroyda, „Teksty Drugie", nr 1, s. 28-40.

Krąpiec Mieczysław A. (2003), Błąd antropologiczny, red. Andrzej Maryniarczyk, Katarzyna Stępień, Polskie Towarzystwo Tomasza z Akwinu, Lublin.

Kunicka Małgorzata (2017), Tomistyczno-fenomenologiczna koncepcja personalizmu Karola Wojtyły wobec kryzysu wartości i wspótczesnych potrzeb edukacyjnych, „Kultura - Media - Teologia”, t. 30, s. 174-183.

Legeżyńska Anna (2019), Biografistyka jako hermeneutyczne wyzwanie, „Teksty Drugie”, nr 1, s. 13-27.

Lejeune Philippe (2001), Wariacje na temat pewnego paktu.

O autobiografii, red. Regina Lubas-Bartoszyńska, przeł. Wincenty Cesluk-Grajewski, Universitas, Kraków.

Madejski Jerzy (2006), Biografia struktury - struktura biografii. Dopiski do teorii Janusza Stawińskiego, w: Dzieła - języki - tradycje, red. Włodzimierz Bolecki, Ryszard Nycz, Edward Balcerzan, Wydawnictwo IBL PAN, Fundacja „Centrum Międzynarodowych Badań Polonistycznych”, Warszawa, s. 28-44.

Madelénat Daniel (1984), La biographie, Presses Universitaires de France, Paris [Francja].

Majchrowski Zbigniew (2014), Listy Mickiewicza jako „archiwum egzystencji”, w: Mickiewicz niedoczytany... Korespondencja poety w perspektywie wspótczesnej, red. Ewa Hoffmann-Piotrowska, Andrzej Fabianowski, Tomasz Jędrzejewski, Wydział Polonistyki Uniwersytetu Warszawskiego, Warszawa, s. 15-25.

Maritain Jacques (1960), Humanizm integralny: zagadnienia doczesne i duchowe nowego świata chrześcijańskiego, przeł. January Budzisz, Veritas, Londyn.

Markowski Michał Pawel (2006), O reprezentacji, w: Kulturowa teoria literatury. Główne pojęcia i problemy, red. Michał Paweł Markowski, Ryszard Nycz, Universitas, Kraków, s. 137-151.

Marzec Lucyna (2018), Archiwum jako pisarski testament i depozyt legendy biograficznej, „Teksty Drugie”, nr 6, s. 231-248.

Nasiłowska Anna (2019), Angielskie, francuskie i polskie tradycje biografistyki. Wprowadzenie do tematu, „Teksty Drugie”, nr 1, s. 41-6o. 
Nycz Ryszard (2002), Tropy „ja”. Koncepcje podmiotowości w literaturze polskiej ostatniego stulecia, w: tegoż, Język modernizmu, Wydawnictwo Uniwersytetu Wrocławskiego, Wrocław, s. 87-117.

Ozorowski Edward, bp (2004), Ontyczne podstawy personalizmu, „Rocznik Teologii Katolickiej”, t. 3, s. 9-18.

Searle John R. (1999a), Umyst, język, społeczeństwo: filozofia i rzeczywistość, przeł. Dominika Cieśla, CiS, WAB, Warszawa.

Searle John R. (1999b), Umyst na nowo odkryty, przel. Tadeusz Baszniak, PIw, Warszawa.

Searle John R. (2010), Umyst. Krótkie wprowadzenie, przeł. Jan Karłowski, Rebis, Poznań.

Sendyka Roma (2015), Od kultury ja do kultury siebie. O zwrotnych formach $w$ projektach tożsamościowych, Universitas, Kraków.

Sławiński Janusz (200o), Biografia [hasło], w: Michał Głowiński, Teresa Kostkiewiczowa Janusz Sławiński, Aleksandra Okopień-Sławińska, Stownik terminów literackich, wyd. 3 poszerz., Ossolineum, Wrocław, s. $67-68$.

Styczeń Tadeusz SDB (2001), Rozum i wiara wobec pytania: Kim jestem?, Towarzystwo Naukowe KUL, Lublin.

Szymonik Marian, ks. (2015), Filozoficzne podstawy kategorii godności człowieka w ujęciu personalizmu szkoły lubelskiej, Wydawnictwo KUL, Lublin.

Tabaszewska Justyna (2019), Na granicy faktu. Kategoria faction w badaniach nad wspótczesnymi biografiami, „Teksty Drugie”, nr 1, s. 61-79.

Terlecki Tymon (1987), Krytyka personalistyczna. Egzystencjalizm chrześcijański, Biblioteka „Więzi”, Warszawa.

Wojtyła Karol (1969), Osoba i czyn, Polskie Towarzystwo Teologiczne, Kraków.

Wojtyła Karol (1986), Miłość i odpowiedzialność, Wydawnictwo TN KUL, Lublin.

Wojtyła Karol (1999), Rozważania o istocie człowieka, WAM, Kraków. Wyka Kazimierz (1963), „Pan Tadeusz”. Studia o poemacie, PWN, Warszawa.

Zabielski Józef, ks. (2014), Personalizm jako imperatyw wartościowania człowieka, „Rocznik Teologii Katolickiej”, t. XIII/1, s. 125-137.

Zagórska Wanda (2004), Uczestnictwo młodych dorostych w rzeczywistości wykreowanej kulturowo: doświadczenie, funkcje psychologiczne, Universitas, Kraków. 
Anita Całek

\section{Personalist biography model in light of the matter of subjectivity}

The article presents a model of personalist biography that stands in opposition to the postmodernist one. The personalist biography model refers in terms of anthropology to Viktor E. Frankl, the founder of logotherapy ('Third Viennese School of Psychotherapy') and the key thinkers of the personalist movement: Karol Wojtyła, Mieczysław Krąpiec, Józef Tischner and Czesław S. Bartnik. Stressing the subjective aspect of biography, the personalist model allows for capturing the personal character of the created biographical portrait of a given person while also taking into account the postulates formed by the critics of biographical writing in its traditional and later structuralist forms, especially the postulates related to the requirement of biographer's objectivity and neutrality. The personalist biography model also takes into consideration the insights of the French theorists on the inevitable involvement of the researcher in the reconstructed picture of a life and the considerations on the character of representation (by F. Ankersmit and M.P. Markowski).

Keywords: biography; biography research; biographical writing; biography theories; personalism; personalist norm; anthropology; representation; epistolography; letter theory.

Anita Całek - absolwentka filologii polskiej (Wydział Filologiczny UJ) oraz psychologii (Wydział Filozoficzny uJ), doktor nauk humanistycznych w zakresie literaturoznawstwa (praca doktorska na temat zastosowania metody psychobiograficznej w analizie porównawczej biografii Adama Mickiewicza i Juliusza Słowackiego). W latach 2003-2008 przebywała w Strasburgu, pracując w Sekcji Polskiej Collège Esplanade i na Université Marc Bloch. Autorka książek: Adam Mickiewicz - Juliusz Stowacki: psychobiografia naukowa (2012), Biografia naukowa: od koncepcji do narracji (2013) i Nowa teoria listu (2019) oraz wielu artykułów naukowych publikowanych w czasopismach i tomach monograficznych. W swoich tekstach porusza różne zagadnienia z zakresu biografii (narracja i narrator, czasoprzestrzeń, metodologia badań biograficznych) oraz epistolografii, pisze również o literaturze współczesnej w ujęciu komparatystycznym. Jest redaktorem naukowym czasopisma „Creatio Fantastica”, współpracuje też z Ośrodkiem Badawczym Facta Ficta. 
